\title{
Central Delta languages: An overview ${ }^{1}$
}

\author{
Ethelbert Emmanuel Kari \\ Department of African Languages and Literature, University of Botswana, Botswana \\ E-mail: ethelbert.kari@ mopipi.ub.bw
}

\begin{abstract}
This paper presents an overview of the phonology, morphology and syntax of Central Delta languages. It also provides information on the geo-linguistic, demographic and sociolinguistic situation of these languages. It notes that Central Delta languages have a 20-vowel system, which divides into two sets of 10 vowels distinguished by pharyngeal size. The consonant systems of these languages range between 22 and 27, showing alternation between some pairs of consonants. Central Delta languages are noted to be rich in nominal and verbal morphologies, showing evidence of prefixal noun classification and morphological marking of nominal and verbal categories. The pronominal systems of these languages make a threeway number-person-case distinction with some of them formally distinguishing between inclusive and exclusive in their first-person plural forms. Common syntactic features observed in these languages include subject-object-verb basic word order and serial verb constructions. The paper highlights the fact that mother-tongue speakers of Central Delta languages also speak one or more other languages and that the daily exposure of Central Delta languages and their speakers to more powerful languages around them makes them endangered. Furthermore, the paper recommends that a survey be undertaken to determine the level of endangerment of Central Delta languages.
\end{abstract}

Keywords: Nigeria, Central Delta languages, nominal and verbal systems, morphology, language endangerment

\section{Introduction}

This paper aims at presenting an overview of the phonology, morphology and syntax of Central Delta languages, including some information on the geo-linguistic, demographic and sociolinguistic situation of these languages. It is divided into six sections. Section 1 introduces the aim of the study and presents geo-linguistic and demographic information and the sources of data. In section 2, information on the linguistic classification and sociolinguistic situation of Central Delta languages is provided. The phonological,

\footnotetext{
${ }^{1}$ I am thankful to Ozo-Mekuri Ndimele for the valuable information he provided on Ochịchi and to Salem Ejeba for the sundry help he offered in the course of writing this paper. I am also thankful to the two anonymous Stellenbosch Papers in Linguistics reviewers for their incisive and enlightening comments that have made this paper richer and better than what it was.
} 
morphological and syntactic overviews of these languages are respectively presented in sections 3 to 5 , while the conclusion is presented in section 6 .

In general, outside of the pedagogical materials published by the Rivers State Readers Project $^{2}$ in and about some of these languages, there is a dearth of literature in and about Central Delta languages in comparison with neighbouring languages, such as Degema (a Delta Edoid language), Kalaḅarị (an Eastern Ijjọ language) and İzọn (a Central Ijọ language). For a partial listing ${ }^{3}$ of the literature available in and about Central Delta languages, see Table 1.

The earliest comparative study (mainly lexical comparison) of Central Delta languages is probably Wolff $(1959,1969)$, in which he lumps Abuan, Odual and Oggịa into what he refers to as "Abuan - Central branch of Niger-Congo". Adoki (2002) describes the sound system of Abuan, Ezeh $(2008,2016)$ deals with the nominal and verbal morphology of Abuan, while Woodman (1983) is on affixation in Abuan. Comson (1987) is a detailed description of the phonology of Oḍal. Alex (1989) is the major unpublished comparative study dealing with the reconstruction of the segmental phonology of Proto-Central Delta. Other studies are Faraclas (1989), which is also comparative in nature but looks at a larger group, namely Cross River, ${ }^{4}$ and highlights some of the features that are common to the group as a whole. Blench (2008) represents a broader attempt to gather the scattered data on the Cross River languages, including Central Delta languages (Blench 2008:iii), even though sections on the phonology, morphology and syntax of Central Delta languages are virtually empty in his documentation.

Although the present study, like Alex (1989), Blench (2008), Faraclas (1989) and Wolff $(1959,1969)$, is a comparative attempt of some sort, it presents a synchronic analysis of this group of languages, like Adoki (2002), Blench (2008), Comson (1987), Ezeh (2008, 2016), Faraclas (1989), Wolff $(1959,1969)$ and Woodman (1983).

\footnotetext{
2 The Rivers Readers Project was a project undertaken from the late 1960s to the late 1970s by the Rivers Readers Committee in collaboration with the then Rivers State Government with the aim of designing orthographies, primers and other pedagogical materials for use in schools in the various communities in the old Rivers State, which included communities in the present Bayelsa State of Nigeria. The Rivers Readers Committee was chaired by Professor Ebiegberi J. Alagoa. Other members of the committee were late Professor Kay Williamson and Professor Otonti A. Nduka and members of the various local language committees. The Rivers Readers Project was reintroduced in 2008 as the Rivers State Readers Project by the Rivers State Government with Dr Tony Enyia as the executive secretary/chief executive officer.

3 There may be materials in and/or about these languages that are either inaccessible or unavailable to the researcher.

${ }^{4}$ The Central Delta languages are classified as a subgroup of Cross River (cf. Faraclas 1989, Williamson 1989b and Williamson and Blench 2000). However, recently Connell, Villa and Nara (2015) and Connell (2016) have posited that these languages do not belong to Cross River but comprise a group that is older than Bantoid Cross and coordinate with Jukunoid, Platoid, etc. within the East Benue-Congo sub-family.
} 
Table 1: A partial listing of literature available on Central Delta languages ${ }^{5}$

\begin{tabular}{|l|l|}
\hline Language name & Available literature \\
\hline Abua & $\begin{array}{l}\text { Adoki (2002); Blench (2008); Ezeh (2008, 2016); Gardner (1973, 1980); } \\
\text { Gardner and Gardner (1966, 1971, 1973); Gardner Azugha, Moopho and } \\
\text { Ofori (1972); Hargrove (2009); Kari and Joshua (2011); Joshua (2006); } \\
\text { Omu (1993); Otto (2000); United Bible Society (1974, 1978); Wolff } \\
(1959,1969) ; \text { Woodman (1983); Woy (1985) }\end{array}$ \\
\hline Oḍual & $\begin{array}{l}\text { Abigo and Gardner (1974); Abigo, Gardner and Gardner (1975); } \\
\text { Blench (2008); Comson (1987); Gardner, Gardner and Abigo (1974); } \\
\text { Gardner (1975); Kari (2007a, 2007b, 2009, 2011); Madumere (2006); } \\
\text { Wolff (1959, 1969) }\end{array}$ \\
\hline Kuggbo & Blench (2008) \\
\hline Aḅureni (Mini) & ---6 \\
\hline Ogbịa & $\begin{array}{l}\text { Blench (2008); Isukul (1986, 2002, 2007); Williamson (1970, 1972); } \\
\text { Wolff (1959, 1969) }\end{array}$ \\
\hline Ogbronụagum & Alex (1987, 1989); Kari (2000) \\
\hline Obulom & Blench (2008); Ngeripaka (2000) \\
\hline Ochịchị & Achonwa (1981) \\
\hline Ogbogolo & Francstan (1995); Olibie (1994) \\
\hline
\end{tabular}

The data for the present study were collected from some of the accessible previous works on Central Delta languages. Data were mainly obtained from Alex (1989), Francstan (1995), Gardner et al. (1974), Isukul (2007), Kari (2000, 2007a, 2007b, 2009), Kari and Joshua (2011), Lewis, Simmons and Fennig (2016), Ngeripaka (2000) and Olibie (1994). The Central Delta languages on or about which linguistic research materials were available for this study are Abuan, Oḍual (Sạkạ), Ọgbịa (Ọgbịnyạ), Ogbrọnụagum (Ḅukuma), Obulom (Abuloma), and Ogbogolo (Obogolo). Due to a lack of research materials or adequate research materials at the time of writing this paper, Kụgbọ, Abureni (Mini) and Ọchịchị are excluded from the discussion in the core areas of linguistics. Also due to a lack of adequate research materials and data, it is not possible to provide illustrative examples from all the languages surveyed to support some of the generalisations that are made in the paper. Needless to say, further data are needed on these languages.

In Table 2, we present the only data available to us on Ọchịchị from Ndimele (2003:13) in which numerals 1-5 in this moribund language are compared with those of other Central Delta languages.

\footnotetext{
${ }^{5}$ See also the Open Language Archives Community (OLAC) at http://www.language-archives.org/language/.

${ }^{6}$ There are no data available on Abureni.

7 We are aware of the existence of a manuscript on Ochịchị (Achonwa 1981), which no doubt is a valuable research material on this moribund language, but we do not as yet have access to it in part or in whole. The pieces of information and limited data we have on Ọchịchị in this paper are from secondary sources, Ndimele (personal communication) and Ndimele (2003), which compare numerals 1-5 in Ọchịchị with those of Echie, Abuan, and Obulom, establishing that Ochịchị is genetically related to Central Delta languages rather than to Echie, an Igboid lect (see Table 2). According to Ndimele, personal communication, "Bro Achonwa was the first to report about the existence of Ochịchị in Etche. He collected a basic wordlist of 100 items with an introductory note in a manually-typed manuscript. It was in his note that he mentioned the relationship of Ochịchi with Echie and Obulom". Also as Blench (2008:3) remarks, "from the few words collected Ọchịchị appears to be related to Obulom, a Central Delta language in turn related to Abua".
} 
Table 2: A comparison of numerals 1-5 in Èchiè, Ọ̀chịchị, Obulom and Abuan ${ }^{8}$

\begin{tabular}{|c|c|c|c|c|}
\hline Èchiè & Òchịchị & Obulom & Abuan & Gloss \\
\hline ótù, ìbó & ǹnén & ùnín & ònîn & "one" \\
\hline àbùj, ṁbj̀̀̀ & İgàl & ì́àl & ìjàl & "two" \\
\hline àtó, tó & ìsàl & İsàr & ìsààr & "three" \\
\hline àṅnó & İnán & ìñ̀ & ìñ̀ & "four" \\
\hline ìsé, sé & $\grave{o ̀ ̀ ~}$ & òò̀ & òó & "five" \\
\hline
\end{tabular}

(adapted from Ndimele 2003:13)

In Table 3, we present a list of Central Delta languages along with their dialects, locations and approximate number of speakers. A map showing the geographical location of Central Delta languages is given in Figure 1.

Table 3: Central Delta languages, location, population and dialects ${ }^{9}$

\begin{tabular}{|c|c|c|c|}
\hline $\begin{array}{l}\text { Language } \\
\text { name }\end{array}$ & Location & $\begin{array}{l}\text { Number of } \\
\text { speakers }\end{array}$ & Dialects \\
\hline Abuan & $\begin{array}{l}\text { Rivers State: Abua-Odual Local } \\
\text { Government Area (LGA) }\end{array}$ & $\begin{array}{l}25000 \\
\text { (Faraclas 1989) }\end{array}$ & $\begin{array}{l}\text { Central Abuan, Emughan, } \\
\text { Otapha (Otabha), Okpeden. } \\
\text { Central dialect understood by } \\
\text { all others. Lexical similarity: } \\
70 \% \text { with Odual }\end{array}$ \\
\hline $\begin{array}{l}\text { Abureni } \\
\text { (Mini) }\end{array}$ & $\begin{array}{l}\text { Bayelsa State: Brass LGA, } \\
\text { Agrisaba (Obo-Emeke), } \\
4 \text { towns; Ogbia LGA, Idema; } \\
\text { Nembe LGA, Okoroba; Ogbia } \\
\text { LGA, Opume; Rivers State: } \\
2 \text { areas }\end{array}$ & $\begin{array}{l}\text { Ethnic population: } \\
4000 \\
\text { (Lewis et al. 2016) }\end{array}$ & - \\
\hline Kụgbọ & $\begin{array}{l}\text { Rivers State: Abua-Odual LGA; } \\
\text { Bayelsa: north Brass LGA }\end{array}$ & 2000 & - \\
\hline Obulom & $\begin{array}{l}\text { Rivers State: Port Harcourt } \\
\text { LGA, Abuloma town }\end{array}$ & $\begin{array}{l}3420 \\
\text { (Lewis et al. 2016) }\end{array}$ & - \\
\hline Ọchịchị & $\begin{array}{l}\text { Rivers State: Etche LGA, towns } \\
\text { of Ikwerrengwo and Umuebulu }\end{array}$ & moribund & - \\
\hline Oḍual & $\begin{array}{l}\text { Rivers State: Abua-Odual LGA; } \\
\text { Bayelsa State: Ogbia LGA }\end{array}$ & $\begin{array}{l}30000 \\
\text { (Comson 1987) }\end{array}$ & $\begin{array}{l}\text { Arughunya, Adibom. Lexical } \\
\text { similarity: 70\% with Abuan } \\
\text { (most similar) }\end{array}$ \\
\hline Ogbịa & $\begin{array}{l}\text { Bayelsa State: Brass and Ogbia } \\
\text { LGAs; Rivers State: Abua- } \\
\text { Odual LGA }\end{array}$ & $\begin{array}{l}200000 \\
\text { (Lewis et al. 2016) }\end{array}$ & $\begin{array}{l}\text { Agholo (Kolo), Oloibiri, } \\
\text { Anyama. Dialect cluster but } \\
\text { all inherently intelligible }\end{array}$ \\
\hline Ogbrọnụagum & $\begin{array}{l}\text { Rivers State: Degema LGA, } \\
\text { Bukuma village near Buguma }\end{array}$ & $\begin{array}{l}12000 \\
(\text { Kari 2000) }\end{array}$ & - \\
\hline Ogbogolo & Bayelsa State: Yenagoa LGA & $\begin{array}{l}10000 \\
\text { (Lewis et al. 2016) }\end{array}$ & - \\
\hline
\end{tabular}

\footnotetext{
${ }^{8}$ The data in Table 1 are transcribed in International Phonetic Alphabet (IPA) symbols, unlike the orthographic ones used by Ndimele (2003).

${ }_{9}^{9}$ The information in Table 3 is updated from Blench (2008), Comson (1987), Faraclas (1989), Kari (2000), Lewis et al. (2016) and from the present author's knowledge of the socio- and geo-linguistic situation of Nigeria. An en-dash "-" in Table 3 indicates that the language in question has no dialect(s).
} 


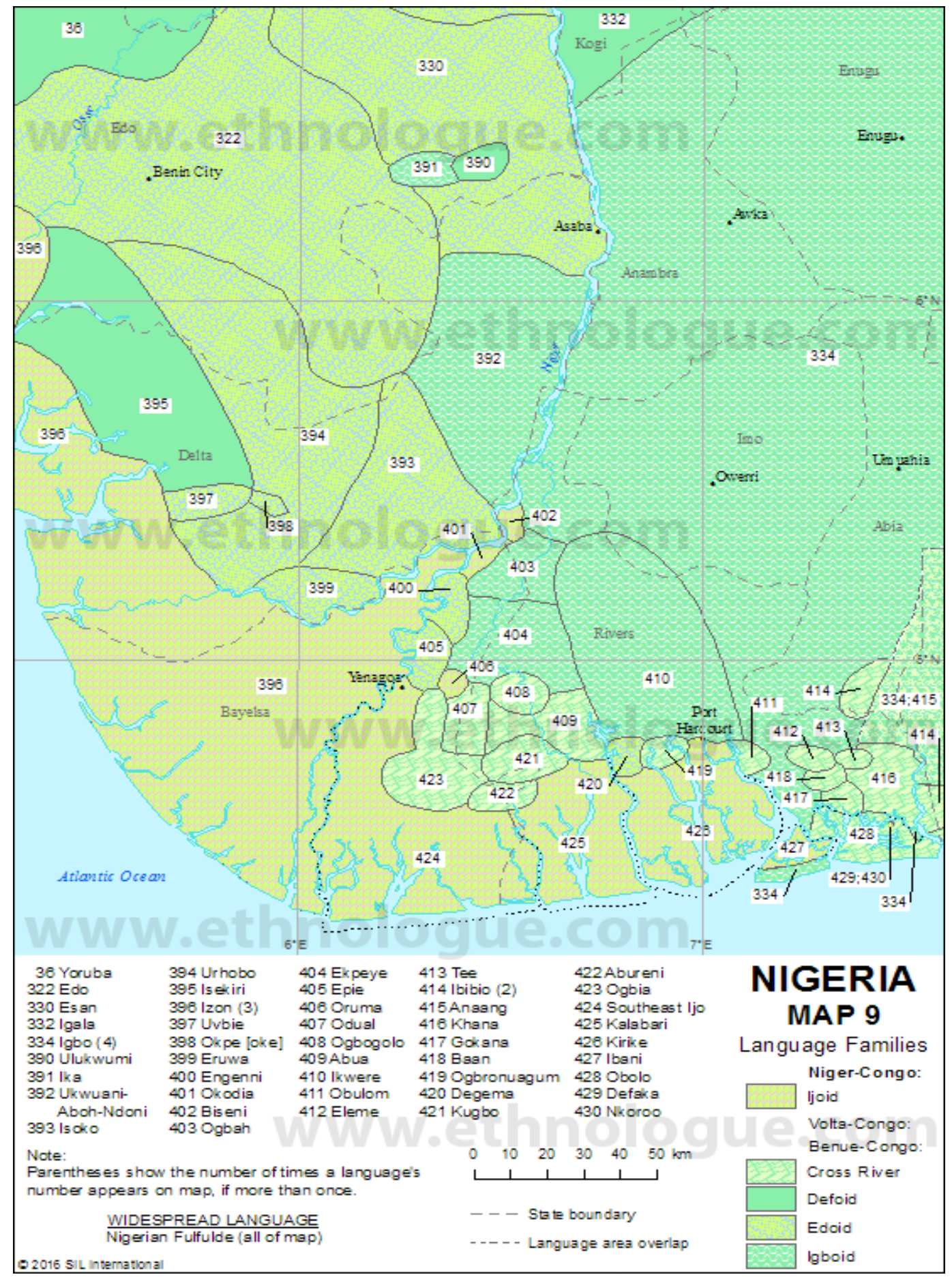

Figure 1: Map showing the geographical location of Central Delta languages (Lewis et al. 2016). ${ }^{10}$

\footnotetext{
${ }^{10}$ The locations of Central Delta languages in Figure 1 are assigned the following numbers: Abua (409), Abureni (422), Kụgbọ (421), Obulom (411), Ọchịchị (not on the map), Oḍual (407), Ọgbịa (423), Ogbrọnụagum (419), Ogbogolo (408).
} 


\section{Background}

The Central Delta languages are a subgroup of East Benue-Congo within the Niger-Congo phylum (cf. Williamson 1989a, Williamson and Blench 2000). They are spoken in the Niger Delta of southern Nigeria in enclaves largely surrounded by speakers of Ijoid languages, such as Kalaḅarị, Kịịkẹ (Okrika) Nembe, İọn and Biseni. Thus, speakers of Central Delta languages speak one or more other languages in addition to their mother tongues. For instance, speakers of Ogbrọnụagum are bilingual in Ogbrọnụagum and Kalaḅarị, a neighbouring Eastern Ijọ language. Obulom speakers are bilingual in Obulom and Okrika, a neighbouring Eastern Ijọ language. The Kụgbọ people speak Kụgbọ and Nembe, an Eastern Ijọ language, in addition to Oḍual and Oggbị (Kolo Creek). In addition to the neighbouring languages spoken by mother tongue speakers of Central Delta languages, younger generations of speakers also speak English and Nigerian Pidgin, which has a much wider currency and is a language of preference among young people.

The linguistic situation in the Delta area, where Central Delta languages are spoken, is such that these languages are exposed daily to the influence of politically and economically more powerful Ijo and other languages that exert pressure on them, thus putting them on the list of endangered languages. Ochịchị, a moribund Central Delta language spoken by the people of Ikwerrengwo and Umuebulu in the Etche Local Government Area of Rivers State and in some parts of Abia State of Nigeria, is a case in point (Ndimele, Kari and Ayuwo 2009:74). Ochịchị speakers have been completely swallowed up by the language and culture of the Etche people, who are speakers of Echie, an Igboid lect (cf. Ndimele 2003). This is the fate that awaits smaller Central Delta languages in the foreseeable future. Having said this, it is recommended that a survey be undertaken to assess or determine the degree of endangerment of Central Delta languages.

\section{Phonological overview of Central Delta languages}

In what follows, we examine aspects of the phonology of Central Delta languages, such as vowels and consonant systems, syllable and morpheme structures, and tonal systems, highlighting the features that are common to these languages.

\subsection{Vowels}

The Central Delta languages on which data are available for the present study operate a 10

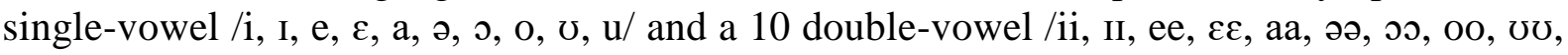
uu/ system, totalling 20 vowels (cf. Abuan: Gardner 1980, Kari and Joshua 2011; Obulom: Ngeripaka 2000; Oḍual: Kari 2009, 2011; Oggbịa: Isukul 2007; Ogbogolo: Olibie 1994, Francstan 1995; and Ogbrọnuagum: Alex 1987, Kari 2000). In these languages, there is a contrast between short and long vowels /i : ii, I : II, e : ee, $\varepsilon: \varepsilon \varepsilon$, a : aa, ə : əə, $ว:$ : , o : oo, $\circlearrowright$ : $v \mho, \mathrm{u}: \mathrm{uu} /$. There are also sequences of vowels (identical and non-identical) in these languages. Inherently nasalised vowels are not attested in Central Delta languages. Nasalised vowels are phonetic, as they are only found in the environment of nasal consonants (cf. Faraclas 1989:388). Table 4 shows the contrasts that exist between long and short vowels in the two Central Delta languages of Abuan and Oḍal. 
Table 4: Long and short vowel contrasts in Central Delta languages

\begin{tabular}{|c|c|c|c|c|c|}
\hline \multicolumn{3}{|c|}{ Abuan (Kari and Joshua 2011:5) } & \multicolumn{3}{|c|}{ Odual (Kari 2011:92f) } \\
\hline \multirow[t]{2}{*}{$\mathrm{i}$ and ii } & kík & "resemble" & $\mathrm{i}$ and ii & ibí & "sequins" \\
\hline & kíly & "kill" & & 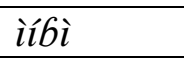 & "good" \\
\hline \multirow[t]{2}{*}{ I and II } & mín & "swallow" & I and II & Íyór & "saliva" \\
\hline & mín & "see" & & $i I^{\downarrow} y^{\prime}$ & "grass" \\
\hline \multirow[t]{2}{*}{ e and ee } & $\grave{e} k u ́$ & "spoon" & e and ee & $\grave{e g} \dot{i}$ & "(of things) many" \\
\hline & éékù & "bottle" & & èégì & "knee" \\
\hline \multirow[t]{2}{*}{$\varepsilon$ and $\varepsilon \varepsilon$} & ذ̀̀lèm & "Creator" & $\varepsilon$ and $\varepsilon \varepsilon$ & $\grave{\varepsilon} b a ́$ & "bag" \\
\hline & ذ̀lı̀̀m & "beard" & & $\grave{\varepsilon}^{\downarrow} \varepsilon^{\downarrow} b a ́$ & "hand, foot" \\
\hline \multirow[t]{2}{*}{$\partial$ and $ә$} & nám & "wink" & $\partial$ and $ә \partial$ & àlàgó & "leaf" \\
\hline & ìnà̀̀m & "nostalgia" & & à̀̀gó & "namesake" \\
\hline \multirow[t]{2}{*}{$\mathrm{a}$ and aa } & j́kàm & "thatch" & a and aa & álágbá & "flag" \\
\hline & j̀kààm & "maker" & & àláá ${ }^{\downarrow} g b a ́$ & "gun" \\
\hline \multirow[t]{2}{*}{ o and oo } & òlóy & "law" & o and oo & òló & "is not" \\
\hline & óòlòy & "wave" & & $\grave{\partial o}{ }^{\downarrow} l o ́$ & "berry" \\
\hline \multirow[t]{2}{*}{$\boldsymbol{o}$ and $\boldsymbol{~} \mathrm{o}$} & ذ̀lè̀m & "beard" & $o$ and $o 0$ & j̀gá & "egg" \\
\hline & j̀̀lèm & "Creator" & & j̀̀gá & "shrimp" \\
\hline \multirow[t]{2}{*}{$\mathrm{u}$ and $\mathrm{uu}$} & òkú & "contribution" & $\mathrm{u}$ and $\mathrm{uu}$ & úbá & "shade" \\
\hline & òòkùùy & "wind" & & $\grave{u} u^{\star} t a ́$ & "(of weather) cold" \\
\hline \multirow[t]{2}{*}{$\mho$ and $\mho \mho$} & İnớn & "birds" & $\mho$ and $v \mho$ & $\dot{\partial j} n u^{\downarrow}$ & "water pot" \\
\hline & nòঠ̀n & "quickly" & & j̀nùưr & "dry season" \\
\hline
\end{tabular}

Vowel harmony is present in all Central Delta languages (see Table 4). The vowel harmony found in these languages is the type known as advanced tongue root $[\mathrm{ATR}]^{11}$, where the size of the pharynx plays a crucial role in distinguishing the vowels. Based on the size of the pharynx, a distinction is made between advanced tongue root [+ATR] vowels (vowels made with the root of the tongue pushed forward with a simultaneous lowering of the larynx) and non-advanced tongue root [-ATR] vowels (vowels made with the root of the tongue pulled backwards with a simultaneous raising of the larynx). The [+ATR] vowels are /i, ii, e, ee, ə,

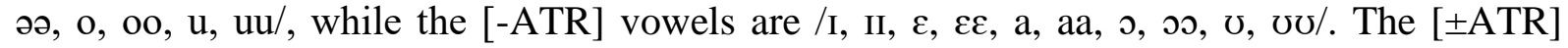
harmony that occurs in these languages is feature-driven, as the [ \pm ATR] feature of vowels of the base spreads on to prefixes and suffixes that attach to the base, causing them to harmonise with the base. The $[ \pm \mathrm{ATR}]$ contrast is carried over to the length contrast in these languages, i.e. short and long vowels show vowel harmony. In most cases, vowels from opposing sets do not co-occur in simple words. Compound and (recently) borrowed words are exceptions to the pervasive vowel harmony rule, as [+ATR] and [-ATR] vowels are found to co-occur in such

\footnotetext{
${ }^{11}$ Abbreviations used in this paper are: $1 \mathrm{SG}=$ first-person singular, $2 \mathrm{SG}=$ second-person singular, $3 \mathrm{SG}=$ thirdperson singular, $1 \mathrm{PL}=$ first-person plural, $2 \mathrm{PL}=$ second-person plural, $3 \mathrm{PL}=$ third-person plural, $1 \mathrm{SGS}=$ firstperson singular subject, $3 \mathrm{SGS}=$ third-person singular subject, aff $=$ affix $(\mathrm{es}), \mathrm{ATR}=$ advanced tongue root, $\mathrm{C}=$ consonant, $\mathrm{CM}=$ concord marker, $\mathrm{DEF}=$ definite article, $\mathrm{DIST}=$ distal, emph. $=$ emphatic, excl./EXCL = exclusive, FACT $=$ factitive, fut. $=$ future, incep. $=$ inceptive, incl./INCL. = inclusive, IPA = International Phonetic Alphabet, NP = noun phrase, num. = number, $\mathrm{O}=$ object, oblig. = obligative, $\mathrm{OFOC}=$ object focus marker, $\mathrm{OM}=$ object marker, $\mathrm{PAST}=$ past, $\mathrm{PERF}=$ perfect, pers. $=$ person, $\mathrm{pl}=$ plural, $\mathrm{PN}=$ personal name, poten. $=$ potential, pref $=$ prefix, pres $/$ PRES. $=$ present, prog/PROG. $=$ progressive, pron. $=$ pronoun, $\mathrm{PROX}=$ proximal, $\mathrm{Q}=$ question, $\mathrm{SG}=$ singular, $\mathrm{SUBJ} . \mathrm{PREF} .=$ subject prefix, $\mathrm{SVC}=$ serial verb construction, $\mathrm{V}=$ vowel, verb.
} 
words. In Oḍual, there are a few words (àlàké "leg", ób́́ $\beta$ “cultivate"), most of which contain the vowel /E/, in which there is co-occurrence of both [+ATR] and [-ATR] vowels so that there is no vowel harmony (Gardner et al. 1974:9; Gardner 1975:15; Kari 2009:5).

Front Central Back

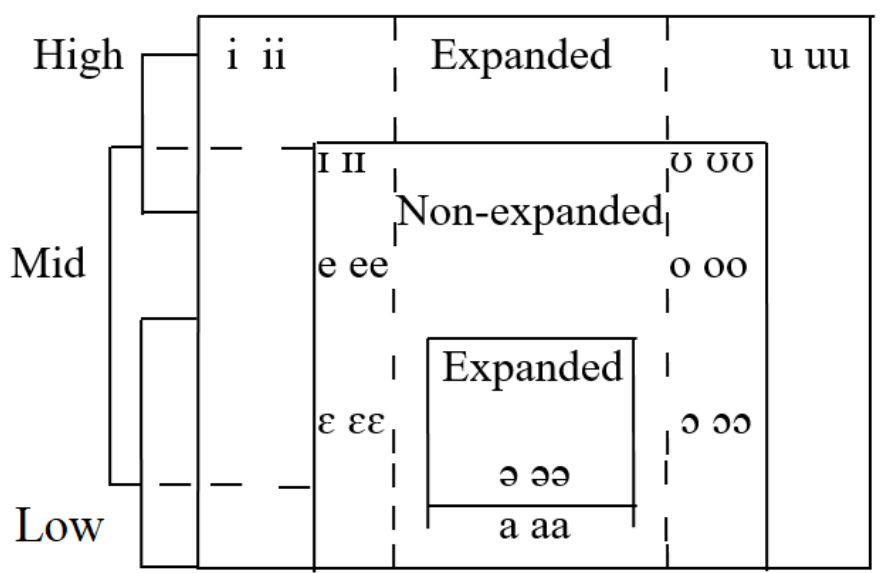

Figure 2: Phonemic vowel inventory of Central Delta languages ${ }^{12}$

\subsection{Consonants}

The number of consonants in Central Delta languages ranges from 22 in Obulom (Ngeripaka 2000) to 27 in Ogbogolo (Olibie 1994; Francstan 1995). Oḍual and Ogbịa have 24 consonants each (Gardner et al. 1974; Comson 1987; Isukul 2007), Ogbrọnụagum has 25 (Kari 2000), while Abuan has 26 (Kari and Joshua 2011). The following is an inventory of consonants in the Central Delta languages for which data is available for this study: /m, n, n, y, ym, $\mathrm{y}^{\mathrm{w}}, \mathrm{p}, \mathrm{b}$, t, d, k, g, kp, gb, 6, d, r, d3, $\phi, \beta, f, v, s, z, \int, y, h, \tilde{h}, 1, j, w /$.

Table 5: Phonemic consonant inventory of Central Delta languages

\begin{tabular}{|c|c|c|c|c|c|c|c|c|}
\hline \multicolumn{2}{|c|}{$\begin{array}{l}\text { Place of articulation } \Rightarrow \\
\text { Manner of articulation } \Downarrow\end{array}$} & Bilabial & $\begin{array}{l}\text { Labio- } \\
\text { dental }\end{array}$ & Alveolar & \multirow{2}{*}{\begin{tabular}{|l|}
$\begin{array}{l}\text { Palatal/ } \\
\text { Velar }\end{array}$ \\
$\mathrm{n}$ \\
\end{tabular}} & Velar & \multirow{2}{*}{\begin{tabular}{|r|}
$\begin{array}{l}\text { Labial- } \\
\text { velar }\end{array}$ \\
$\mathrm{ym}$ \\
\end{tabular}} & \multirow{2}{*}{\begin{tabular}{|c|}
$\begin{array}{l}\text { Labialised- } \\
\text { Velar/Glottal }\end{array}$ \\
$\mathrm{y}^{\mathrm{w}}$ \\
\end{tabular}} \\
\hline $\mathbf{S}$ & Nasal & $\mathrm{m}$ & & $\mathrm{n}$ & & y & & \\
\hline $\begin{array}{l}\mathbf{T} \\
\mathbf{O}\end{array}$ & Plosive & $\mathrm{b}$ & & $\mathrm{d}$ & & $\mathrm{k}$ & $\mathrm{kp} \quad \mathrm{gb}$ & \\
\hline $\mathbf{P}$ & Implosive & 6 & & d & & & & \\
\hline \multirow[t]{2}{*}{$\mathbf{S}$} & Trill/Roll & & & $\mathrm{r}$ & & & & \\
\hline & Africate & & & $\mathrm{d}_{3}$ & & & & \\
\hline \multicolumn{2}{|c|}{ FRICATIVE } & $\phi$ & $\mathrm{v}$ & $\mathrm{Z}$ & $\int$ & $\mathrm{\gamma}$ & & $h(\tilde{h})$ \\
\hline \multicolumn{2}{|c|}{ APPROXIMANT } & & & 1 & $\mathrm{j}$ & & $\mathrm{w}$ & \\
\hline
\end{tabular}

\footnotetext{
${ }^{12}$ Figure 2, adapted from Kari (2000:3), illustrates the ATR type of vowel harmony in Central Delta languages. The large box represents an expanded pharynx [+ATR], while the small box represents a non-expanded pharynx [ATR]. The smaller box, which also represents an expanded pharynx [+ATR], is placed inside the small box to show the symmetrical arrangement of the vowels. The vertical broken lines demarcate front, central and back vowels.
} 
From the total number of consonants listed against each of the six languages mentioned above (Abuan, Obulom, Odual, Ogbịa, Ogbogolo and Ogbrọnụagum), it is obvious that not one of the Central Delta languages has all consonants in the inventory. In this regard, Abuan has all consonants except $/ \mathrm{y}^{\mathrm{w}}, \phi, \mathrm{z}, \int, \mathrm{h}, \tilde{\mathrm{h}} /$; Obulom has all consonants except $/ \mathrm{y}, \mathrm{ym}, \mathrm{\eta}^{\mathrm{w}}, \phi, \mathrm{v}, \mathrm{z}, \int, \mathrm{\gamma}$, $\tilde{\mathrm{h}} / ;$ Odual has all consonants except /nm, d3, $\phi, \int, \mathrm{h}, \tilde{\mathrm{h}} / ;$ Ọgbịa has all consonants except /ym, $\phi, \int, \mathrm{h}, \tilde{\mathrm{h}} /$; Ogbogolo has all consonants except $/ \mathrm{ym}, \mathrm{y}^{\mathrm{w}}, \mathrm{h}, \tilde{\mathrm{h}} /$; and Ogbrọnụagum has all consonants except /nm, $\phi, \beta, \mathrm{z}, \int, \mathrm{h} /$.

An interesting feature of Central Delta languages, as far as consonant systems are concerned, is the alternation between some of the consonants. There are different inventories for steminitial as opposed to stem-medial/final consonants. Such inventories for stem-initial vs. stemfinal consonants are not found in Obulom and Ogbia, at least not in the data obtained from the source materials on these languages. The alternations between some of these consonants are noted in Abuan (Gardner 1980:xf.), Ogbrọnuagum (Alex 1987:66; Kari 2000:28f.) and in Oḍual (Madumere 2006:47ff; Kari 2009:10ff.). In Ogbrọnụagum and Oḍual, alternations are observed to occur in words between the pairs of consonants [t] and [r] and [k] and [Y], depending on their position in the words in which they occur. It is observed that the consonants [t] and [k] occur word-initially in imperatives in Ogbrọnugaum and Oḍual. However, when these consonants occur intervocalically, i.e. when they are preceded by the infinitive vowel prefix, [t] becomes [r] and [k] becomes [V] in both languages. As in Ogbrọnụagum and Oḍual, alternations are observed to occur in words in Abuan between the following pairs of consonants: $[\mathrm{t}]$ and $[\mathrm{r}]$ and $[\mathrm{k}]$ and $[\mathrm{Y}]$. Alternations also occur between $[\mathrm{p}]$ and $[\mathrm{w}]$ in Ogbrọnụagum and between $[\mathrm{p}]$ and $[\beta]$ in and Oḍual:

\section{(1) Abuan}

Alternation between $[\mathrm{t}]$ and $[\mathrm{r}]$

àbìdí kò-tú "they will come" àbìdí mó-rúù "they have come"

Alternation between $[\mathrm{k}]$ and $[\mathrm{Y}]$

jóór kj̀-kí "we will go" jóór mó- -Iì "we have gone"

(2) Oḍual

Alternation between $[\mathrm{p}]$ and $[\beta]$

pùrá "stink" óßúrá "to stink"

Alternation between [t] and [r]

tùYèćl "return" órúYéćl "to return"

Alternation between [k] and [Y]

kìràńn "turn around" ófíráán "to turn around"

\section{(3) Ogbrọnụagum}

Alternation between [p] and [w]

pàrà "reply" àríwáàrà "to reply" 
Alternation between [t] and [r]

tèlè "walk" òríréèlè "to walk"

Alternation between $[\mathrm{k}]$ and $[\mathrm{Y}]$

kìlè "do" àrífîllè "to do"

However, exceptions occur between these alternating pairs of consonants in Odual (Kari 2009:10f) and Ogbrọnụagum (Kari 2000:28f) respectively. In Oḍual, exceptions are found to exist between the pairs $[\mathrm{p}]$ and $[\beta],[\mathrm{t}]$ and $[\mathrm{r}]$, and $[\mathrm{k}]$ and $[\gamma]$, as illustrated in (4), (5) and (6), respectively.

\begin{tabular}{|c|c|c|c|c|c|}
\hline (4) & pùú & “surpass" & $\sim$ & ópú & "to surpass" \\
\hline & pі̀pì $\beta$ & "lick" & $\sim$ & śpíí $\beta$ & "to lick" \\
\hline & pèćl & "jump" & $\sim$ & ópéćl & "to jump" \\
\hline (5) & tòj̀nmàán & "follow" & $\sim$ & śtưónmán & "to follow" \\
\hline & tòtìá & "remember" & $\sim$ & óśtúá & "to remember" \\
\hline & tờyá & "learn" & $\sim$ & ótướyá & "to learn" \\
\hline (6) & kùlàón & "touch (with hand)" & $\sim$ & ókúláán & "to touch (with hand)" \\
\hline & kùó & "pluck (fruit)" & $\sim$ & śkó & "to pluck (fruit)" \\
\hline & kàá & "carve (wood)" & $\sim$ & óká & "to carve (wood)" \\
\hline & kذ̀tว̀n & "untie" & $\sim$ & ókótón & "to untie" \\
\hline
\end{tabular}

Similarly, in Ogbronụagum, exceptions are found between the pairs $[\mathrm{t}]$ and $[\mathrm{r}],[\mathrm{p}]$ and $[\mathrm{w}]$, and $[\mathrm{k}]$ and $[\mathrm{\gamma}]$, as illustrated in (7), (8) and (9), respectively.

\begin{tabular}{|c|c|c|c|c|c|}
\hline (7) & $\begin{array}{l}\text { tòm } \\
\text { tờá }\end{array}$ & $\begin{array}{l}\text { "follow" } \\
\text { "learn" }\end{array}$ & $\tilde{\sim}$ & $\begin{array}{l}\text { àrí-túùm } \\
\text { àrí-túờwà }\end{array}$ & $\begin{array}{l}\text { "to follow" } \\
\text { "to learn" }\end{array}$ \\
\hline (8) & $\begin{array}{l}\text { pùùrù } \\
\text { pòòm }\end{array}$ & $\begin{array}{l}\text { "ask (question)" } \\
\text { "cover (pot)" }\end{array}$ & $\sim$ & $\begin{array}{l}\text { ̀̀rí-púùrù } \\
\text { òrí-póòm }\end{array}$ & $\begin{array}{l}\text { "to ask (question)" } \\
\text { "to cover (pot)" }\end{array}$ \\
\hline (9) & $\begin{array}{l}\text { kùtò } \\
\text { kj̀ }\end{array}$ & $\begin{array}{l}\text { "pierce (ear)!" } \\
\text { "build" }\end{array}$ & $\sim$ & $\begin{array}{l}\text { àrí-kúùtò } \\
\text { àrí-kj́j }\end{array}$ & $\begin{array}{l}\text { "to pierce (ear)!" } \\
\text { "to build" }\end{array}$ \\
\hline
\end{tabular}

\subsection{Syllable/morpheme structures}

Alex (1989) shows that Central Delta languages have three basic syllable types: V, CV and CVC. A syllable of the type VC is also attested (see Kari 2009). A V syllable type consist of a vowel only, a CV type consists of a consonant and a following vowel, a CVC type consists of two consonants with an intervening vowel, while a VC type consists of a vowel and a following consonant. Syllabic nasals are attested in languages such as Abuan, Oḍal and Ogbrọnuagum. Consonant clusters of the type CCV are attested, but these are surface structures that result from the deletion of an intervening vowel. 
Noun prefixes in Central Delta languages predominantly have V(V)-, VC- and VCV(V)forms. Longer forms, such as VCVmu- and VCVrU- ${ }^{13}$, are also attested in Odual, but these occur only in the plural (see Table 6). Verbal suffixes are basically -V, -VC, -CV, -VCV and CVC forms (see Table 17).

Table 6: The structure of noun prefixes in Central Delta languages

\begin{tabular}{|c|c|c|c|}
\hline Prefixes & $\begin{array}{l}\text { Abuan } \\
\text { (Gardner 1980) }\end{array}$ & $\begin{array}{l}\text { Oḍual } \\
\text { (Kari 2006, 2009) }\end{array}$ & $\begin{array}{l}\text { Ogbronụagum } \\
\text { (Kari 2000) }\end{array}$ \\
\hline $\mathrm{V}(\mathrm{V})-$ & $\begin{array}{l}\dot{o} \text {-wòl "leg" } \\
\dot{j} \text {-kpj̀ "bone" }\end{array}$ & $\begin{array}{l}\text { ̀̀-dèvà "bees (swarm of)" } \\
\text { à̀े-bàdì "iguana" }\end{array}$ & $\grave{e}$-kpé "he-goat" \\
\hline $\mathrm{VCV}(\mathrm{V})-$ & $\begin{array}{l}\text { àró-yú "penises" } \\
\text { d̀rúú-kùm "knees" }\end{array}$ & $\begin{array}{l}\text { ̀̀rà-dèvà "bees (swarms of)" } \\
\text { ̀̀rùú-dùúm "bushes" }\end{array}$ & àrù-gùnù "bellies" \\
\hline VC- & $-{ }^{14}$ & - & àw-rówrì “men” \\
\hline VCVmu- & - & 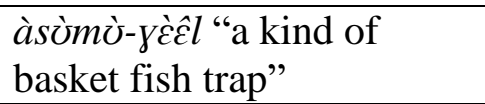 & - \\
\hline VCVrU- & 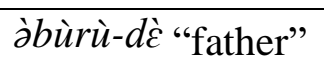 & àbùrì-màràní "sisters" & - \\
\hline
\end{tabular}

\subsection{Tone}

Alex (1989:24) remarks that "all Central Delta lects operate a basic two-tone system". These tones are low tone, which is marked with a grave accent ( ' ), and high tone, which is marked with an acute accent (') ${ }^{\prime}$. There is also a downstep phenomenon in these languages. The downstep is marked with a small arrow pointing downwards $\left(^{\downarrow}\right.$ ) between two high-toned syllables. Apart from the syllabic nasal, tone in these languages is anchored on vowels. Table 7 shows these tones and downstep as found in Abuan, Oḍual and Ogbrọnuagum.

Table 7: Tones in Central Delta languages

\begin{tabular}{|c|c|c|c|c|c|}
\hline \multicolumn{2}{|c|}{$\begin{array}{l}\text { Abuan } \\
\text { (Kari and Joshua 2011:8) }\end{array}$} & \multicolumn{2}{|c|}{$\begin{array}{l}\text { Oḍual } \\
\text { (Kari 2009: 9, 12) }\end{array}$} & \multicolumn{2}{|c|}{$\begin{array}{l}\text { Ogbrọnụagum } \\
\text { (Kari 2000:9) }\end{array}$} \\
\hline òlòm & "husband" & ózú & "to pour" & égù & "fear" \\
\hline$\grave{o l} l^{\downarrow} \dot{m}$ & "to bite" & òzú & "skin" & ègú & "louse" \\
\hline ólóm & "paddle" & $\grave{\partial \sigma^{\downarrow} \beta O ́}$ & "bark of tree" & ònîn $n i ́$ & "one" \\
\hline
\end{tabular}

Like in lexical items, tone can distinguish grammatical constructions in Central Delta languages. In Odual, for instance, tone is found to distinguish between statements and questions (Kari 2009:12), as shown in (10):

$$
\begin{aligned}
& \text { a. } \quad \text { òdí ná-kòdí. } \\
& \text { 3SGS 3SG.PRES PROG-sleep } \\
& \text { "He is sleeping." }
\end{aligned}
$$

\footnotetext{
${ }^{13} \mathrm{C}$ and $\mathrm{V}$ represent underspecified consonant and vowel, respectively.

${ }^{14}$ An en-dash "-" indicates that noun prefixes with the structure in question are not attested in the language.
} 
(b) òdí ná-kòdì.

3SGS 3SG.PRES PROG.Q-sleep

"Is he sleeping?"

\section{Morphological overview of Central Delta languages}

This section discusses the nominal and verbal systems of Central Delta languages. In particular, it looks at noun classification; concordial relationships; case marking; pronominal systems; and verb morphology, especially the marking of grammatical categories and verbal extensions.

\subsection{Nominal morphology}

Central Delta languages show evidence of noun classification. Nominal morphology in these languages is characterised by the presence of prefixes. Nouns consist of a stem and a prefix, which in most cases agrees with the vowels of the stem in \pm ATR. Plural formation is essentially by a replacement of a singular marking prefix with a plural marking prefix. There are singular, plural and single class-marking prefixes, which do not have any plural counterparts. Single class-marking prefixes are associated with non-count nouns. The prefixes are of different shapes and lengths. They are semantically determined and form the basis for the classification of nouns in these languages into genders. The semantic content of these genders includes human, lower animals, plants/plant parts, artefacts, parts of the body, human relationships and non-count. Nominal prefixes in Ogbịa and Ogbogolo are mostly single vowels. It is only what Isukul (2007:141) calls the "generalised plural prefix marker that has the shape ArA-. The shape of the generalised plural prefix marker in Ogbia looks more like those of many of the prefixes in other Central Delta languages like Abuan, Obulom, Odual and Ogbrọụagum, which have canonical V(V) and VCV(V) shapes.

Suffixation is not common in non-derived nouns. Evidence of suffixation is attested in derived forms, such as gerunds, in Ogbogolo and Ogbịa (Olibie 1994; Francstan 1995; Isukul 2007), as illustrated in section 4.5. Interfixation is rare but found in derived nouns in Ogbogolo (Francstan 1995) and Oggbịa (Isukul 2007). According to Isukul (2007:93), "many of the nominals derived from the interfixation of -mA- stand for occupation or profession", as seen in (11) taken from Isukul (2007:93):

\begin{tabular}{|c|c|c|c|c|}
\hline ògbè $\beta$ & édian & $>$ & ògbèßmàèdì̀n (sg) & $\begin{array}{l}\text { "farmer/cultivator" } \\
\text { "farmers/cultivators" }\end{array}$ \\
\hline to grow & food & & & \\
\hline ogbàl & غ́nam & $>$ & ogbàlmà̇̀nàm (sg) & "shepherd" \\
\hline o rear & beasts & & غ̇gbàlmàc̀nàm (pl) & "shepherds" \\
\hline$\grave{g} g \hat{u}$ & irérén & $>$ & ògùmàírérén (sg) & "wood cutter" \\
\hline to cut & trees & & igùmàírérén (pl) & "wood cutters" \\
\hline gìy & ína & $>$ & ògìymàìnà (sg) & "fisherman" \\
\hline o kill & fish & & ìgìymàinà (pl) & "fishermen" \\
\hline
\end{tabular}

Languages such as Abuan, Oḍual, Oggbịa, Ogbogolo and Ogbrọnụagum show that demonstratives, adjectives, and modifier nominals have number-marking prefixes whereby in many cases the forms o-/oo- and o-/os- and i-/ii- and I-/II-, depending on the \pm ATR of the vowels of the stem, are used to mark singular and plural, respectively. Table 8 shows the 
forms of demonstratives, adjectives and nominal modifiers in the Central Delta languages of Oḍual and Ogbrọnụagum.

Table 8a: Demonstratives

\begin{tabular}{|c|c|c|c|}
\hline \multicolumn{2}{|c|}{ Ogbrọnụagum (Kari 2000:19) } & \multicolumn{2}{|c|}{ Oḍual (Kari 2009:28) } \\
\hline j̀jdì & "this" & $\grave{\partial} \dot{\partial} \beta \dot{O}$ & "this" \\
\hline èédì & "these" & òpó & "that" \\
\hline$\grave{j p j ̀ ~}$ & "that" & ì̈ßá & "these" \\
\hline pèédì & "those" & ìpá & "those" \\
\hline
\end{tabular}

Table 8b: Adjectives and modifier nominals

\begin{tabular}{|c|c|c|c|}
\hline \multicolumn{2}{|c|}{ Adjectives: Ogbrọụagum (Kari 2000:22) } & \multicolumn{2}{|c|}{ Modifier nominals: Oḍual (Kari 2009:38) } \\
\hline òblibûî́fblibúî & "black" & óbílélíbílé & "one that is black" \\
\hline j̇blàbáà/îblàbáà & "white" & j́báál/íbáál & "one that is white" \\
\hline ògbóóná/igbóóná & "big" & ògbàáf/ìgbàáy & "one that is big/large" \\
\hline ódùúdù/ídùúdù & "small" & j̀bàmóî̀bàm & "one that is small" \\
\hline
\end{tabular}

\subsection{Concordial relationship}

There are some instances of limited concordial agreement in which number-marking prefixes of demonstratives, adjectives, and modifier nominals have a phonological shape that is similar or identical to noun prefixes in Central Delta languages (see Gardner 1980; Olibie 1994; Kari 2000, 2009; Isukul 2007). This concordial relationship is purely in respect to number-marking and not in terms of noun classes (cf. Swahili, Lyons 1968:285). For example, the form of the demonstrative $\dot{d} d i$ ("this") in Ogbrọụagum does not vary irrespective of the gender to which the noun it is used with belongs (e.g. áárì "woman" + j́dì "this" > át-rí '́-dì "this woman" : j̀dírí "book" + j́-dì "this" > ̀̀-dírí '́-dì "this book"). This is unlike in Bantu languages such as Swahili (Lyons 1968: 285), where in many cases modifiers change their prefixes to reflect the class of the noun (e.g. wa-tu "people" + wa-zuri "beautiful" + wa-le "those" > wa-tu wa-zuri wa-le "those beautiful people"; $m$ - $t i$ "tree" + mi-zuri "beautiful" + $i$-le "those" > m-ti mi-zuri $i$ $l e$ "those beautiful trees"). In Swahili, the adjective and the demonstrative have the prefix wa-, because the noun wa-tu ("people") belongs to the human class, whereas with nouns that belong to the class of trees or plants such as m-ti ("tree"), the prefixes of the adjective and demonstrative become $m i$ - and $i$-, respectively.

The existence of concordial relationships in Central Delta languages in terms of noun classes, if any, is limited and without general applicability. Table 9 shows the concordial relationship between nouns and modifiers in Oḍual and Ogbrọnụagum 
Table 9: Concordial relationship between nouns and modifiers

\begin{tabular}{|c|c|c|c|c|}
\hline \multicolumn{3}{|c|}{ Adjectives: Ogbrọnụagum (Kari 2000:43f) } & \multicolumn{2}{|c|}{ Modifier nominals: Oḍal (Kari 2009:28) } \\
\hline $\begin{array}{l}a^{\downarrow} r^{\prime} \\
\text { woman }\end{array}$ & $\begin{array}{l}\text { ódì } \\
\text { this }\end{array}$ & "this woman" & $\begin{array}{ll}\text { òtù } & \text { oó } \beta o ́ \\
\text { house } & \text { SG.PROX }\end{array}$ & "this house" \\
\hline $\begin{array}{l}\text { àwát rí } \\
\text { women }\end{array}$ & $\begin{array}{l}e ́ d i ̀ \\
\text { these }\end{array}$ & "these women" & $\begin{array}{l}\text { àrùtù iíßa } \\
\text { houses PL.PROX }\end{array}$ & "these houses" \\
\hline $\begin{array}{l}\text { òmóóm } \\
\text { new }\end{array}$ & $\begin{array}{l}\text { j̀làsì } \\
\text { bag }\end{array}$ & "a new bag" & $\begin{array}{ll}\text { òtù } & \text { ópó } \\
\text { house } & \text { SG.PROX } \\
\end{array}$ & "that house" \\
\hline $\begin{array}{l}\text { ògbóón } \\
\text { big }\end{array}$ & $\begin{array}{l}\text { órèn } \\
\text { tree }\end{array}$ & "a big tree" & $\begin{array}{l}\text { àrùtù ipá } \\
\text { houses PL.DIST }\end{array}$ & "those houses" \\
\hline
\end{tabular}

\subsection{Case marking}

Case marking in nouns is not a general feature of Central Delta languages. However, in Odual, nouns are morphologically marked for accusative and locative cases. It is noted that direct object noun phrases are preceded by the accusative case marker $\mathbf{m}-$, as in (12a), while those indicating location, as in (12b), are preceded by the locative case marker t-. Similarly, in Ogbia, noun phrases functioning as sentential objects are marked for accusative case. The form of the accusative case marker, which precedes the object in Ogbịa, is identified as -m- in Isukul (1986) and later as $\mathbf{m A -}$ - in Isukul (2007). The form $\mathbf{m A -}$ - harmonises in \pm ATR with the vowels of the following object, as in (13):

$$
\begin{aligned}
& \text { a. ààmì ú-yàá m-ว́ßéréćr. } \\
& \text { I 1SG.PAST-buy OM-book } \\
& \text { "I bought a book" }
\end{aligned}
$$

(Oḍual: Kari 2009:16)
b. ààmì ú-rùú mò-yč̀̀l t-ót tú.
I 1SG.PAST-want INF-go LOC-house

"I wanted to go home"

(Oḍual: Kari 2009:16)

$$
\begin{aligned}
& \text { a. nwá nááfél mà-ànáné? } \\
& \text { you look.PRES OM-who } \\
& \text { "You're looking for who?" }
\end{aligned}
$$

b. nwá nááfél mà-غ̀níce?

you want.PRES OM-how many

"You want how many?"

(Ọgbịa: Isukul 2007:123)

\subsection{Pronouns}

The pronominal systems of Central Delta languages make a three-way distinction in person, number and case. Person distinctions are first, second and third. In terms of number, the languages distinguish between singular and plural. The case distinctions in pronouns are subject, object and possessive. There is no biological or gender distinction in the pronominal systems of these languages, as a look at the personal pronominal systems of Abuan, Oḍual and Ogbịa in Table 10 shows. A noteworthy feature of some Central Delta languages with regard to their pronominal systems is the presence of inclusive and exclusive pronouns. The 
inclusive-exclusive distinction is overtly expressed in the forms of the first-person plural personal pronouns. According to Givón (1984:354), this distinction “...pertains to the hearer's inclusion in or exclusion from, the referential scope of 'we'. 'We-INCL' is thus 'we, including you", and 'we-EXCL' is thus "we, excluding you"'. The reason for the overt distinction in the forms of the first-person plural pronouns is well expressed by Givón (1984). In his view, “....inclusion/exclusion are not directly predictable from the speaker and hearer, they are potentially ambiguous in the speech situation, and it is thus only natural that they may require overt specification ('marking')" (Givón 1984:355).

Central Delta languages that morphologically mark the inclusive-exclusive distinction in the forms of first-person plural personal pronouns are Abuan (Gardner 1980) and Oḍual (Kari 2007b, 2009), as seen in Table 10.

Table 10: Personal pronouns in Abuan, Oḍual and Ọgbịạ

\begin{tabular}{|c|c|c|c|c|c|c|c|c|c|c|c|c|}
\hline \multirow{2}{*}{$\begin{array}{l}\text { Num/ } \\
\text { pers. }\end{array}$} & \multicolumn{4}{|c|}{ Subject } & \multicolumn{4}{|c|}{ Object } & \multicolumn{4}{|c|}{ Possessive } \\
\hline & Abuan & \begin{tabular}{|l|} 
Odual \\
\end{tabular} & Ogbia & Gloss & Abuan & Odual & Ogbia & Gloss & Abuan & Odual & Ogbia & Gloss \\
\hline $1 \mathrm{sg}$ & mí & \begin{tabular}{|l|} 
áámí \\
\end{tabular} & àmì & "I" & Ímì & áámí & mààmì & "me" & àmì & áámí & dáámí & "my" \\
\hline $2 \mathrm{sg}$ & ná & $a^{\downarrow} n a ́$ & ànwá & "you" & ínà & $a^{\star} n a ́$ & màànwá & "you" & \begin{tabular}{|l} 
ànà \\
\end{tabular} & ónú ${ }^{\star} m a ́$ & dáíjóm & "your" \\
\hline 3sg & $\partial d I^{15}$ & òdí & ह̀nà & $\begin{array}{l}\text { "s/he } \\
\text { /it" }\end{array}$ & nj̀dÍ & òdí & mà̀̀nà & $\begin{array}{l}\text { "her/him } \\
\text { /it" }\end{array}$ & $\grave{j} d \grave{~}$ & ódí & dăíjó & $\begin{array}{l}\text { "her/his } \\
\text { /its" }\end{array}$ \\
\hline 1pl & -16 & - & İjàr & "we" & - & - & màìjàr & "us" & - & 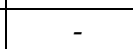 & dáíjár & "our" \\
\hline $\begin{array}{l}\text { 1pl } \\
\text { (incl.) }\end{array}$ & jírà & èzìrá & -- & "we" & jírò & èzìrá & -- & "us" & àjìr̀̀ & ézzi $r a ́$ & -- & "our" \\
\hline $\begin{array}{l}\text { 1pl } \\
\text { (excl.) }\end{array}$ & júśor & ézáár & -- & "we" & Íjj̀̀r & ézáár & -- & "us" & àjòòr & ézáár & -- & "our" \\
\hline 2pl & nínà & èèná & ìnin & "you" & nínà & èèná & màìnin & "you" & ànìǹ̀ & 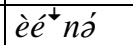 & dáinin & "your" \\
\hline 3pl & àbìdÍ & èèdí & ว̀w & "they" & bìdí & èèdí & mààwà & "them" & àbìdì & èédí & dăáwá & "their" \\
\hline
\end{tabular}

\subsection{Verbal morphology}

Like nominal morphology, Central Delta languages are rich in verbal morphology. Grammatical categories such as person, number, tense, aspect and negation are to a large extent morphologically marked. Faraclas (1989:391) remarks that "verbs in Central Delta languages are inflected primarily via a system of prefixes". It is interesting to note that some of the inflectional markers in these languages, like Oḍual, are not strictly prefixes but discontinuous morphemes. Negative-marking, in some cases, is a combination of prefixes and lexical items (see Kari 2009). The affixes that mark these grammatical categories in most cases harmonise in \pm ATR with the vowels of the stem to which they attach. In general, it is observed that segmental (affixes and lexical items) and non-segmental (tone) morphemes combine to express not only person, but also number, tense, aspect, negation and modality.

\footnotetext{
15 Third-person singular and plural forms as listed under Abuan in Table 10 are those used to refer to human beings. Gardner (1980:ix) remarks that "a non-human singular pronoun, $\varepsilon d I$, and non-human plural pronoun, $I d I$, occur very infrequently".

16 A single dash in Table 10 "-” indicates that Abuan and Oḍal do not have first-person plural forms of pronouns that do not make inclusive and exclusive distinctions, while double dashes "--" indicate that Oggbia (Isukul 2007) does not make inclusive and exclusive distinctions in first-person plural pronouns.
} 
Verbs consist of a stem to which one or more inflectional affixes can be attached. Phonologically, the verb stem begins with a consonant. Verbal derivation yielding infinitives, imperatives and gerunds is through affixation. In Oḍual, Oggbịa, Ogbogolo and Ogbrọụagum, for instance, infinitives are formed by prefixation. Gerunds are formed by suffixation in Ọgbịa and Ogbogolo but by circumfixation in Oḍual.

\section{Table 11a: Verbal derivatives}

\begin{tabular}{|c|c|c|c|}
\hline Derivative & Abuan & Odual & Ogbịa \\
\hline Infinitive & lóm "bite" > ò-ló ${ }^{\downarrow} \dot{m}$ "to bite" & tèlé "walk" > ó-rélé "to walk" & gir "work" > ò-gir "to work" \\
\hline Gerund & sá “cook" > j-sá-yán "cooking” & sàá "cook"> j-sàà-j "cooking" & $\begin{array}{l}\text { ò-mèn "to fall" > ò-mèn-èkù } \\
\text { "falling" }\end{array}$ \\
\hline Imperative & $\begin{array}{l}\text { sá (sg) > Í-sà-yàn “cook! (pl.)" } \\
\text { ká-sá “don’t cook! (sg)" } \\
\text { kí-sá “don’t cook! (pl)""17 }\end{array}$ & $\begin{array}{l}\text { kèél "go"> i-kéèl "go!" } \\
\text { u-yéél-yà "don’t go! (sg)" } \\
\text { i-yèèl-yà "don’t go! (pl)" }\end{array}$ & $\begin{array}{l}\text { sà “cook!" } \\
\text { kj̀-sá “don’t cook! (sg)" } \\
\text { j̀ì̀-kj̀-sá “don’t cook! (pl)" }\end{array}$ \\
\hline Agentives & -18 & $\begin{array}{l}\text { tàám "send"> ó-tám-áày "sender" } \\
\text { bàáy "build" > ó-6áy-áày "builder" } \\
\text { kìll "run" > ókil íkìll "runner" }\end{array}$ & $\begin{array}{l}\text { ò-rùòm "to send" } \\
\text { o-rùòm-d̀dòm "sender" }\end{array}$ \\
\hline
\end{tabular}

\section{Table 11b: Verbal derivatives}

\begin{tabular}{|c|c|c|}
\hline Derivative & Ogbonuagum & Ogbogolo \\
\hline Infinitive & $n \grave{~}$ "defecate" àrí-níi "to defecate" & rò “dwell" à-ró "to dwell" \\
\hline Gerund & sòwù “cut” àrí-sówù “cutting” & à-rúà “to learn" à-róà-nì "learning"19 \\
\hline Imperative & $n \grave{a}(\mathrm{sg}) \sim$ I-nà “give! (pl)” & gbé "grind" j̀-gbéé "grind!" \\
\hline Agentives & 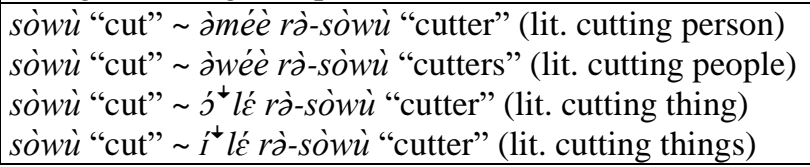 & á-wòlì "to sell" òní-á-wòlì "seller" \\
\hline
\end{tabular}

Two types of imperative constructions exist in Odual: the positive imperative and negative imperative. In positive imperative constructions involving a singular subject, verbs are in their citation forms. However, in the plural the verb stem is preceded by a high-toned numberperson-marking prefix Íl-, which agrees with the stem vowels in \pm ATR. In negative imperative constructions, the subjects are clearly marked for number and person by different low-tone prefixes attached to the verb stem. The number-person-marking prefix attached to the verb stem in the negative imperative singular is $\mathbf{U}$-, while the prefix $\mathbf{I}-$ is attached to the verb stem in the negative imperative plural (see Kari 2009:61f.), as Table 11a shows.

Negative imperatives in Abuan are marked by two prefixes - a singular marking prefix kÁand a plural marking prefix kí-, as shown in Table 11a.

In Oḍual, agentives are derived by circumfixation and reduplication. Two forms of the circumfix I- ... - VVj and $\mathbf{O}-\ldots-\mathbf{V V \mathbf { j }}$ are used in the derivation. Verb stems that end with a vowel take $\mathbf{I}-\ldots-\mathbf{V V j}$, while those that end with a consonant take $\mathbf{O}-\ldots-\mathbf{V V \mathbf { j }}$, as shown in Table 11a (see also Kari 2009:41f.). Agentive nominals in Ogbrọnụagum have a verb stem

\footnotetext{
${ }^{17}$ I am grateful to Pamela Umor, a native speaker of Abuan, for providing relevant data on Abuan.

${ }^{18}$ In Abuan, agentives are not morphologically derived, but are expressed using periphrastic expressions (Pamela Umor, personal communication).

${ }^{19}$ Francstan (1995:41) notes that "in Ogbogolo, the gerund is irregular in its formation. A variety of morphemes are affixed to the root of the verb".
} 
preceded by an $\mathbf{r V}$ morpheme, which in turn is preceded by a noun. The noun is àméè ("person") for singular and j̀wéè ("people") for plural when the agent is human but $j^{\downarrow} l \varepsilon ́$ ("thing") for singular and $I^{\downarrow} l \varepsilon$ ' ("things") for plural when the agent is an instrument (see Kari 2000:30), as shown in Table 11b.

In the following tables, i.e. Tables 12-16, we present forms of affixes attached to verbs to express the inflectional categories of person, number, tense, aspect, negation and modality in Oḍual and Ogbrọnụagum. ${ }^{20}$

Table 12: Forms of verb affixes marking non-past in positive constructions in Oḍual

\begin{tabular}{|c|c|c|c|c|c|c|c|c|c|c|c|}
\hline \multirow[t]{2}{*}{ Num./pers. } & \multicolumn{2}{|c|}{$\begin{array}{l}\text { Simple present } \\
\text { (with) }\end{array}$} & \multirow{2}{*}{\begin{tabular}{|l}
$\begin{array}{l}\text { Pres. } \\
\text { prog. }\end{array}$ \\
\end{tabular}} & \multirow[t]{2}{*}{$\begin{array}{l}\text { Pres. } \\
\text { perf. }\end{array}$} & \multirow[t]{2}{*}{ Fut. } & \multicolumn{2}{|c|}{ Potential } & \multicolumn{2}{|c|}{ Optative } & \multicolumn{2}{|c|}{ Conditional } \\
\hline & $\begin{array}{l}d i \\
\text { "be" } \\
\text { "be }\end{array}$ & other verbs & & & & V1 aff. & $\begin{array}{l}\text { V2 } \\
\text { aff. }\end{array}$ & $\begin{array}{l}\text { V1 } \\
\text { aff. }\end{array}$ & $\begin{array}{l}\text { V2 } \\
\text { aff. }\end{array}$ & V1 aff. & V2 aff. \\
\hline \multirow{3}{*}{$\begin{array}{l}1 s g \\
2 s g \\
3 s g\end{array}$} & Ó- & nÁ-...-VÁ & nÁ- & nÁÀ- & tÁ- & tÁ-...-nÍ & Á- & nÁ- & mÓ- & À- & tÁ-...-nÍ \\
\hline & Ó- & nÁ-...-YÁ & nÁ- & nÁÀ- & tÁ- & tÁ-...nÍ & Á- & nÁ- & mÓ- & $\grave{\mathrm{A}-}$ & tÁ-...-nI \\
\hline & Ó- & $\mathrm{nÁ}-\ldots-\mathrm{VÁ}$ & $\mathrm{nÁ}-$ & nÁÀ- & tÁ- & tÁ-...-nÍ & Á- & nÁ- & mÓ- & $\overline{\mathrm{A}}-$ & $\mathrm{t} \hat{A}-\ldots-n \mathrm{n}$ \\
\hline \multirow{4}{*}{$\begin{array}{l}\text { 1pl (incl.) } \\
\text { 1pl (excl.) } \\
2 \mathrm{pl} \\
3 \mathrm{pl}\end{array}$} & Ú- & nÓ-...-YÁ & nÓ- & nÓÒ- & tÓ- & tÓ-...-ní & Ó- & nÓ- & mÓ- & Ò- & tÓ-...-nÍ \\
\hline & Ú- & nÓ-...-YÁ & nÓ- & nÓÒ- & tÓ- & tÓ-...n-nÍ & Ó- & nÓ- & mÓ- & Ò- & tÓ-...-nI \\
\hline & İ- & nÉ-...-VÁ & nÉ- & nÉÉ- & tÉ- & té-...n-n'́ & É- & nÉ- & mÓ- & Ë- & tÉ-...-nI \\
\hline & İ- & nÉ-...-VÁ & nÉ- & nÉÈ- & tÉ- & tÉ-...n-nI & É- & nÉ- & mÓ- & È- & tÉ-...-nÍ \\
\hline
\end{tabular}

Table 13: Forms of verb affixes marking past in positive constructions in Oḍual

\begin{tabular}{|c|c|c|c|c|c|c|c|c|c|}
\hline \multirow[t]{2}{*}{ Num/pers. } & \multirow{2}{*}{$\begin{array}{c}\begin{array}{c}\text { Past } \\
\text { (with) }\end{array} \\
\text { rì'l form } \\
\text { of } d{ }^{\prime} \text { "be" }\end{array}$} & \multicolumn{2}{|c|}{ Past } & \multicolumn{2}{|c|}{ Past prog. } & \multicolumn{2}{|c|}{ Potential } & \multicolumn{2}{|c|}{ Optative } \\
\hline & & $\begin{array}{l}\text { Emph } \\
\text { pref. }\end{array}$ & $\begin{array}{l}\text { Non- } \\
\text { emph } \\
\text { pref. }\end{array}$ & V1 aff. & $\begin{array}{c}\text { V2 } \\
\text { pref. }\end{array}$ & V1 aff. & $\begin{array}{c}\text { V2 } \\
\text { pref. }\end{array}$ & $\begin{array}{c}\text { V1 } \\
\text { pref. }\end{array}$ & V2 pref.+pl \\
\hline \multirow{3}{*}{$\begin{array}{l}1 s g \\
2 s g \\
3 s g\end{array}$} & $\grave{\mathrm{A}}-\ldots-\mathrm{Y} \grave{\mathrm{A}}$ & Ù- & $\grave{A}-$ & ÚÙ-...-VÀ & mÒ- & kÚ-...-nÍ & $\grave{\mathrm{A}}-$ & Ú- & mò- ${ }^{21}$ \\
\hline & $\grave{A}-\ldots-\bigvee \grave{A}$ & Ú- & $\grave{A}-$ & ÚU̇-...-VÀ & mÒ- & kÚ-...-nÍ & $\grave{A}-$ & Ú- & mò- \\
\hline & $\grave{\mathrm{A}}-\ldots-\mathrm{V} \overline{\mathrm{A}}$ & Á- & $\grave{A}-$ & $\overline{\mathrm{A}} \grave{\mathrm{A}}-\ldots-\mathrm{V} \grave{\mathrm{A}}$ & mÒ- & kÚ-...-nÍ & $\grave{A}-$ & Á- & mò- \\
\hline \multirow{4}{*}{$\begin{array}{l}\text { 1pl (incl.) } \\
\text { 1pl (excl.) } \\
\text { 2pl } \\
3 p l\end{array}$} & Oे-...-УÀ & Ú- & Oे- & ÚÙ-...-VÀ & mOे- & kÚ-...-nÍ & À- & Ú- & mò-....̇̀Ù \\
\hline & Ò-...-УÀ & Ù- & Ò- & ÚÙ-...-VÀ & mÒ- & kÚ-...-nÍ & $\grave{A}-$ & Ú- & mò-... ĖУÙ \\
\hline & È-...-V̀̃ & Í- & Eे- & III-...-VÀ & mÒ- & kíl-...-nÍ & È- & Í- & mò-... Ėyப் \\
\hline & $\grave{E}-\ldots-\mathrm{V} \grave{\mathrm{A}}$ & Í- & È- & $\widehat{\mathrm{II}}-\ldots-\mathrm{V} \AA \mathrm{A}$ & mÒ- & kÍ-...n-nÍ & È- & Í- & mò-... ĖУÙ \\
\hline
\end{tabular}

Table 14: Forms of negative-marking verb affixes/morphemes in Oḍal

\begin{tabular}{|c|c|c|c|c|}
\hline \multirow[t]{2}{*}{ Num/pers. } & \multicolumn{2}{|c|}{ Present progressive/past/future } & \multicolumn{2}{|r|}{ Present perfective } \\
\hline & Prefix & Post-verbal lexical item & Prefix & Post-verbal lexical item \\
\hline \multirow{3}{*}{$\begin{array}{l}1 \mathrm{sg} \\
2 \mathrm{sg} \\
3 \mathrm{sg} \\
\end{array}$} & Ú- & Cìó & dÒ- & Cìó \\
\hline & Ò- & Cìó & $\mathrm{dÒ}$ & Cìó \\
\hline & Ò- & Cìó & dÒ & Cìó \\
\hline \multirow{4}{*}{$\begin{array}{l}\text { 1pl (incl.) } \\
\text { 1pl (excl.) } \\
\text { 2pl } \\
\text { 3pl }\end{array}$} & Ú- & Cìó & dÒ & Cìó \\
\hline & Ú- & Cìó & $\mathrm{dÒ}$ & Cìó \\
\hline & I- & Cìó & $\mathrm{dÒ}$ & Cìó \\
\hline & İ- & Cìó & $\mathrm{dÒ}$ & Cìó \\
\hline
\end{tabular}

\footnotetext{
${ }^{20}$ A detailed description of the affixes presented in Tables 12-16 can be found in Kari (2000, 2009).

${ }^{21}$ The form of V2 prefix is actually mò-, not $\mathbf{m}$ - as listed by Kari (2009:59).
} 
Table 15: Forms of verb affixes marking non-past in positive constructions in Ogbrọnụagum

\begin{tabular}{|c|c|c|c|c|c|c|c|c|c|c|c|c|}
\hline \multirow[t]{2}{*}{ Num./pers. } & \multirow{2}{*}{\begin{tabular}{|l|} 
Lexical \\
subject \\
pronoun
\end{tabular}} & \multirow[t]{2}{*}{ Proclitic } & \multicolumn{4}{|c|}{ Factative (with) } & \multirow{2}{*}{$\begin{array}{l}\text { Pres. } \\
\text { prog. }\end{array}$} & \multirow{2}{*}{\begin{tabular}{|l|} 
Pres. \\
perf.
\end{tabular}} & \multirow[t]{2}{*}{ Fut. } & \multirow{2}{*}{\begin{tabular}{|c|} 
Poten./ \\
oblig.
\end{tabular}} & \multirow[t]{2}{*}{ Opt. } & \multirow[t]{2}{*}{ Incep. } \\
\hline & & & $\begin{array}{l}d i ́ \\
\text { "be" }\end{array}$ & $\begin{array}{l}\text { m'́ } \\
\text { "have" }\end{array}$ & \begin{tabular}{|l|} 
other \\
verbs $^{22}$
\end{tabular} & \begin{tabular}{|l|} 
other \\
verbs $^{23}$
\end{tabular} & & & & & & \\
\hline $1 \mathrm{sg}$ & ààmí & $\mathrm{N}$ & $\mathrm{mÁ}-$ & $\mathrm{mÁ}-$ & mÁ KÁ & jÉÈ- & rÁ- & KÁ- & TÁ- & dÁ- & rÁ- & KÁ-24 \\
\hline $2 \mathrm{sg}$ & já & Í & $\mathrm{jÁ}-$ & $\mathrm{mÁ}-$ & $\mathrm{mÁ} \sim \mathrm{KÁ}$ & jÉÈ- & rÁ- & KÁ- & TÁ- & $\mathrm{dÁ}-$ & rÁ- & KÁ- \\
\hline $3 s g$ & $j z ́$ & $\varnothing$ & Á- & mÁ- & $\mathrm{mÁ} \sim \mathrm{KÁ}$ & jÉÈ- & rÁ- & KÁ- & TÁ- & dÁ- & rÁ- & KÁ- \\
\hline 1pl & ว̀jó & Ò & Á- & $\mathrm{mÁ}-$ & mÁ KÁ & jÉÈ- & rÁ- & KÁ- & TÁ- & $\mathrm{dÁ}-$ & rÁ- & KÁ- \\
\hline $2 \mathrm{pl}$ & èní & $\grave{\mathrm{E}}$ & Á- & $\mathrm{mÁ}-$ & mÁ $\sim \mathrm{KÁ}$ & jËÈ- & rÁ- & KÁ- & TÁ- & dÁ- & rÁ- & KÁ- \\
\hline 3pl & àbá & $\varnothing$ & Á- & mÁ- & $m A ́ \sim K A ́$ & jÉÈ- & rÁ- & KÁ- & TÁ- & dÁ- & rÁ- & KÁ- \\
\hline
\end{tabular}

Table 16: Forms of negative-marking verb affixes/morphemes in Ogbrọnụagum

\begin{tabular}{|c|c|c|c|c|c|}
\hline Num./pers. & $\begin{array}{l}\text { Lexical } \\
\text { subject } \\
\text { pronoun }\end{array}$ & Proclitic & $\begin{array}{l}\text { Factative/prog./perf./ } \\
\text { fut./poten./oblig./opt. }\end{array}$ & Pres. prog. & $\begin{array}{l}\text { Pres. perf./ } \\
\text { inceptive }\end{array}$ \\
\hline \multirow{3}{*}{$\begin{array}{l}1 \text { sg } \\
2 \text { sg } \\
3 \text { sg }\end{array}$} & ààmí & $\mathrm{N}$ & Ń- & Ń- & Ń-d⿵- \\
\hline & já & jÁ & $\varnothing$ & $\varnothing$ & Ń-dÀ- \\
\hline & $j \dot{z}$ & Á & $\varnothing$ & $\varnothing$ & Ń-dÀ- \\
\hline \multirow{3}{*}{$\begin{array}{l}1 \text { pl } \\
2 \text { pl } \\
3 \text { pl }\end{array}$} & j̀jó & Òjí & $\varnothing$ & $\varnothing$ & Ń-dÀ- \\
\hline & ènní & Èjí & $\varnothing$ & $\varnothing$ & Ń-dÀ- \\
\hline & àbá & Ú & $\varnothing$ & $\varnothing$ & Ń-dÀ- \\
\hline
\end{tabular}

\subsection{Verb extensions}

Verbs in Central Delta languages may also take, in addition to inflectional affixes, one or more extensional suffixes or verbal extensions. In most cases, extensional suffixes harmonise with the vowels of the verb stem in \pm ATR. These suffixes do not alter the lexical category of the verbs to which they attach. Instead, they modify the lexical meaning as well as change the valency of such verbs. The variety of meanings expressed by these suffixes include causative, reflexive, reciprocal, iterative, benefactive, associative, initiative, instrumental, accompaniment and directive. These suffixes are attested in Abuan (Gardner 1980), Obulom (Ngeripaka 2000), Ogbịạ (Isukul 2007) and Ogbogolo (Olibie 1994).

Table 17 shows that no given Central Delta language has all the verb extensions listed herein. For instance, in Abuan, only six (causative, reflexive, benefactive, associative, instrumental and accompaniment) out of the 10 extensions listed above are attested. The iterative, reciprocal, initiative and directive are not attested in Abuan. In Obulom, only two (iterative and associative) extensions are attested; the others are not. Likewise, in Ogbịa only two (reciprocal and initiative) extensions are attested; the others are not. Similarly, in Ogbogolo only two (instrumental and directive) extensions are attested; the others are not.

\footnotetext{
${ }^{22}$ These are forms that occur with dynamic verbs without obligatory, lexical/non-clitic forms of subject pronouns.

${ }^{23}$ These are forms that occur with dynamic verbs with obligatory, lexical/non-clitic forms of subject pronouns.

${ }^{24}$ See Kari (2000) for a discussion of the underlying forms of these affixes in Ogbronụagum.
} 
Table 17: Extensional suffixes ${ }^{25}$

\begin{tabular}{|c|c|c|c|c|}
\hline Meaning & Abuan & Obulom & Ogbịa & Ogbogolo \\
\hline Causative & $\begin{array}{l}-\mathrm{E}^{26}: \text { bèc̀n-ć “cause } \\
\text { to cross" }\end{array}$ & - & - & - \\
\hline Reflexive & $\begin{array}{l}\text {-A : búr-á “cover } \\
\text { oneself” }\end{array}$ & - & - & - \\
\hline Iterative & -27 & $\begin{array}{l}\text {-(V)jAn : pèm-ìján } \\
\text { "jump about" }\end{array}$ & - & - \\
\hline Reciprocal & - & - & $\begin{array}{l}\text {-An : òtùl-̀̀n } \\
\text { "to love each other" } \\
\text {-An : sgbàmày-àn } \\
\text { "to accuse each } \\
\text { other" }\end{array}$ & - \\
\hline Benefactive & $\begin{array}{l}\text {-(v)nAAn : pàm- } \\
\text { ànáán "hold for" }\end{array}$ & - & - & - \\
\hline Associative & $\begin{array}{l}\text {-An : tùy-àn "live } \\
\text { together" }\end{array}$ & $\begin{array}{l}\text {-(V)jAn : lòm-ìján } \\
\text { "bite together" }\end{array}$ & - & - \\
\hline Initiative & - & - & $\begin{array}{l}\text {-kú : dè-kơ “eat } \\
\text { first”" }\end{array}$ & - \\
\hline Instrumental & $\begin{array}{l}\text {-Om : l’̀-óm "put } \\
\text { with" }\end{array}$ & - & - & $\begin{array}{l}\text {-lu : ikú-lú } \\
\text { "touch with hand" }\end{array}$ \\
\hline $\begin{array}{l}\text { Accom- } \\
\text { paniment }\end{array}$ & $\begin{array}{l}\text {-mOm : tù-móm } \\
\text { "come with" }\end{array}$ & - & - & - \\
\hline Directive & - & - & - & $\begin{array}{l}\text {-ni : àgbé-nì } \\
\text { "send somebody to } \\
\text { do something" }\end{array}$ \\
\hline
\end{tabular}

\section{Syntactic overview of Central Delta languages}

The discussion in this section focuses on basic word order in simple sentences, the patterns of modification in nominal phrases in these languages, and serial verb constructions (SVCs).

\section{$5.1 \quad$ Word order}

Central Delta languages have a subject-verb-object (SVO) basic word order in simple sentences or independent clauses, as exemplified by Oḍual, Ọgbịa, Ogbogolo and Ogbrọnụagum.

$$
\begin{array}{lll}
\mathbf{S} & \mathbf{V} & \mathbf{O} \\
\text { èdìyótù } & \text { á-míin } & \text { ḋ }^{\downarrow} \text { bádí. } \\
\text { PN } & \text { PAST-see } & \text { iguana } \\
\text { "Edighotu saw an iguana" } &
\end{array}
$$

(Oḍual: Kari 2009:70)

\footnotetext{
${ }^{25}$ From what we have in Table 17, Abuan is richer in extensional suffixes than other Central Delta languages.

${ }^{26}$ This transcription, rendered in IPA, deviates from Gardner's orthographic transcription.

${ }^{27}$ An en-dash in Table 17 indicates that a given verbal extension is not attested in the language under consideration.
} 
(15)

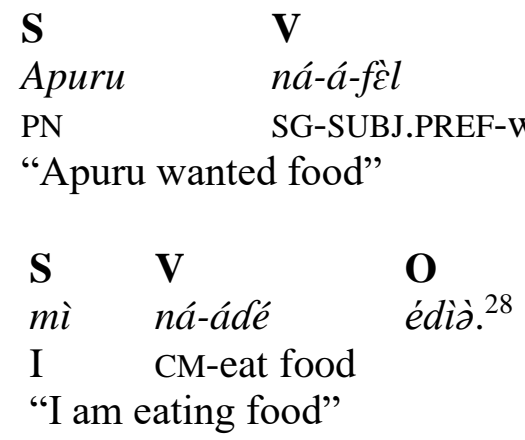

$\mathbf{O}$ màédì̀n.

(Ogbịa: Isukul 2007:147)

food

$\begin{array}{llll}\mathbf{S} & \mathbf{V} & \mathbf{O} & \\ \text { j̀lèmáàdì } & \text { má-sá } & \text { ámómbò } & \text { j̀. } \\ \text { PN } & \text { 3SG.FACT-cook } & \text { soup } & \text { DEF } \\ \text { “Olemaadi cooked the soup” } & & \end{array}$

(Ogbogolo: Olibie 1994:56)

"Olemaadi cooked the soup"

However, there are deviations from the basic SVO word order, as found in cleft constructions in which the logical object is preposed. In such constructions, the verb comes last, as examples from Abuan (18), Oḍual (19) and Ogbrọnụagum (20) show:
a. mí à-mìn $\quad$ j̇̀n $\beta \dot{b}^{29}$
I PAST-see boy the
"I saw a boy." (Abuan)
b. j́j̀n $\beta \dot{n}$ kèdí mí à-mì̀n.
boy the CLEFT I PAST-see
"It was the boy I saw."

(19)

$\begin{array}{llll}\text { a. } & \grave{d} \text { dìyótù } & \grave{a} \text {-mîin } & \text { át ábádí. } \\ & \text { PN } & \text { PAST-see } & \text { iguana }\end{array}$

"Edighotu saw an iguana." (Oḍual)
b. à̀bàdì $\quad \beta o ́ \quad$ èdiyótù à-mín.

iguana CLEFT PN PAST-see
"It was an iguana Edighotu saw."
a. èyólú à ká-ráàlù jogú á. goat DEF FACT-chew vegetables DEF "The goat ate the vegetables." (Ogbrọnụagum)
b. jo jwó j́gó $\quad$ á nó é $e^{\downarrow}$ yólú á á-rààlò. it be vegetables DEF OFOC goat DEF FACT-chew "It was the vegetables that the goat ate."

\footnotetext{
${ }^{28}$ Olibie and Francstan orthographic transcription are rendered in this paper in symbols that have IPA values.

${ }^{29}$ I am thankful to Pamela Umor and Isaiah Edighotu for data showing deviations from the basic SVO word order in Abuan and Oḍual, respectively.
} 
It is observed in these languages that different morphemes feature as markers of cleft constructions. In Abuan, the cleft marker is $k \dot{\varepsilon} d \dot{\prime}$, in Odual the morpheme is $\beta o ́$, while in Ogbrọnụagum $j^{\downarrow} w \tilde{u}$ serves as the cleft marker.

In noun phrase $(\mathrm{NP})$ constructions, such as noun + article, noun + possessive, noun + interrogative pronoun, noun + modifier nominal, and noun + demonstrative, word order appears to be uniformly consistent in Central Delta languages. In many cases, modifiers that precede and follow the head noun appear to be the same in these languages. It is observed that the definite article and demonstratives, for instance, follow the noun in Odual, Ogbịa, Ogbogolo $^{30}$ and Ogbrọnugagum, while adjectives/modifier nominals, quantifiers, and interrogatives precede the noun in Oḍual, Oggbịa, Ogbogolo and Ogbrọnụagum:

$$
\begin{aligned}
& \text { énò ’̀ } \\
& \text { fish DEF } \\
& \text { "the fish" } \\
& \text { (Ogbrọnụagum: Kari 2000:43) }
\end{aligned}
$$

$$
\text { òtù òóßó }
$$

house this

"this house"

(Oḍual: Kari 2009:28)

òk̀̀rá áàj

which person

"which person"

(Oḍual: Kari 2009:32)

$$
\begin{aligned}
& \text { j̀gàrà jò́kì } \\
& \text { small chair } \\
& \text { "a small chair" } \\
& \text { (Ọgbịa: Isukul 2007:148) }
\end{aligned}
$$

$$
\begin{aligned}
& \text { ònón ótù } \\
& \text { this house } \\
& \text { "this house" }
\end{aligned}
$$$$
\text { (Q̣bịa: Isukul 2007:147) }
$$

$$
\begin{aligned}
& \text { òtù } \grave{\partial} \phi \grave{\partial} \\
& \text { house the } \\
& \text { "the house" } \\
& \text { (Ogbogolo: Olibie 1994:17b) }
\end{aligned}
$$

òlòirí $\quad \begin{aligned} & \beta a ́ \\ & \text { man }\end{aligned}$ that
“the man"
(Ọgbịạ: Isukul 2007:115)

$$
\begin{aligned}
& \text { j̀áéré érérémú } \\
& \text { which tree } \\
& \text { “which tree?" } \\
& \text { (Ogbogolo: Francstan 1995:35) }
\end{aligned}
$$

\begin{tabular}{ll}
$\begin{array}{l}\text { ògbóóná } \\
\text { big } \\
\text { "a big tree" }\end{array}$ & \multicolumn{1}{c}{$\begin{array}{l}\text { ón } \\
\text { tree }\end{array}$} \\
(Ogbrọnụagum: Kari 2000:23) \\
j̀máná & j̀dìdì \\
this & rope \\
"this rope" & \\
(Ogbogolo: Olibie 1994:37)
\end{tabular}

\subsection{Serial verb constructions}

Serial verbs are common in Central Delta languages. These verbs, which are linked without any overt connective morpheme, share a common surface subject and one or more tense, aspect and polarity markers. Among the semantic notions expressed by serial verbs in these languages are sequential (31), locative (32), comparative (33), and benefactive (34) (cf. Olibie 1994:55; Kari 2000:48, 2009:74):

\footnotetext{
${ }^{30}$ Ogbịa and Ogbogolo behave differently in respect to the demonstrative-noun relationship. In these languages, the demonstrative precedes the noun.
} 


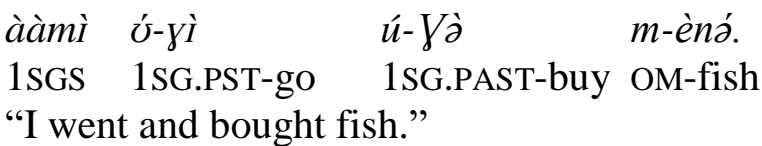

(Oḍual: Kari 2009:74)

$o^{\downarrow} d o ́$ nà ádí ná ágí òlògì òtù.

Odo CM enter CM go inside house

"Odo entered into the house."

(Ogbogolo: Olibie 1994:55)

àmón ám á-nìc á-tè àmón wóò.

child my 1SG.FACT-be beautiful 1SG.FACT-be more than child yours

"My child is more beautiful than yours." ～(Ogbrọnugam: Kari 2000:48)

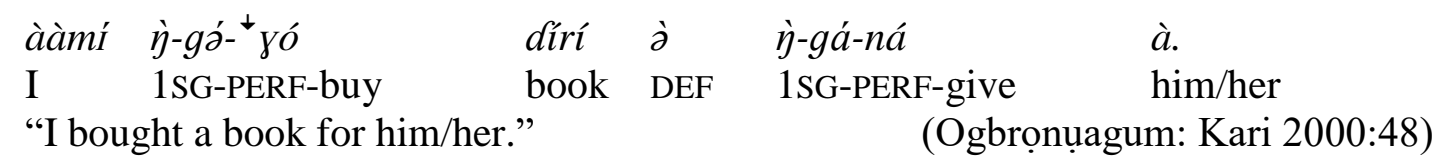

SVCs in Central Delta languages belong to the type that Williamson (1989a) calls "concordial' SVC. Each verb refers to the subject by means of a concordial marker or pronoun (Williamson 1989a:30), as seen in the Oḍual (31), Ogbogolo (32) and Ogbrọụagum (33) and (34). See also Kari (2003) for a similar discussion.

\section{Conclusion}

In this paper, we have provided phonological, morphological and syntactic overviews of Central Delta languages, including aspects of the geo- and sociolinguistic situation of these languages. We noted that Central Delta languages have a 20 -vowel system, which divides into two sets of 10 vowels distinguished by the size of the pharynx. We also noted that the consonant systems of these languages range between 22 and 27, showing alternation between some pairs of consonants, such as $[\mathrm{t}]$ and $[\mathrm{r}],[\mathrm{k}]$ and $[\mathrm{\gamma}],[\mathrm{p}]$ and $[\mathrm{w}]$, and $[\mathrm{p}]$ and $[\beta]$, determined by whether such consonants occur word-initially or intervocally in imperatives and infinitives. Furthermore, we noted that Central Delta languages are generally rich in nominal and verbal morphologies, showing evidence of prefixal noun classification, and that the morphological marking of grammatical categories such as person, number, tense, aspect and negation is by means of discontinuous morphemes in some cases. The personal pronominal systems of these languages make a three-way number-person-case distinction, with some of them (Abuan and Oḍual) formally distinguishing between inclusive and exclusive in their first-person plural forms. Some common syntactic features observed in these languages are subject-object-verb basic word order with similar patterns of modification in nominal and verbal phrases, as well as serial verb constructions. Finally, we highlighted the fact that mother-tongue speakers of Central Delta languages also speak one or more other languages and that the daily exposure of these languages and their speakers to more powerful languages around them makes them endangered. We recommended that a survey be undertaken to assess or determine the degree of endangerment of Central Delta languages. 


\section{References}

Abigo, M. and A. Gardner. 1974. Aselemi obel obhereer ịtuugha onu Oḍal (Odual Reader I). Ibadan-Port Harcourt: Institute of African Studies and Rivers State Ministry of Education.

Abigo, M., A. Gardner and I. Gardner. 1975. Reading and writing Odual. Ibadan-Port Harcourt: University of Ibadan and Rivers State Ministry of Education.

Achonwa, B. 1981. Glimpse of Òchịchì - A near-extinct language of the Etche. Unpublished manuscript. Port Harcourt: University of Port Harcourt School of Humanities.

Adoki, E. 2002. The sound system of Abuan. Unpublished BA long essay. Port Harcourt: University of Port Harcourt.

Alex, I. 1987. The phonology and word structure of Bukuma. Unpublished BA long essay. Port Harcourt: University of Port Harcourt.

Alex, I. 1989. A reconstruction of the segmental phonology of Proto-Central Delta. Unpublished MA thesis. Port Harcourt: University of Port Harcourt.

Blench, R. 2008. The Central Delta languages: Comparative word list and historical reconstructions. Available online: http://www.rogerblench.info/Language/NigerCongo/BC/Cross \%20River/Central\%20Delta/Comparative\%20Central\%20Delta.pdf (Accessed 31 October 2015).

Comson, E.E. 1987. The phonology of Odual. Unpublished BA long essay. Port Harcourt: University of Port Harcourt.

Connell, B. 2016. Cross River. To appear in V. Vydrin (Ed.) Towards Reconstructing NigerCongo. Language Sciences Press.

Connell, B., E. Villa and K. Nara. 2015. A phylogenetic classification of the Cross River languages based on lexical evidence. Paper presented at the 8th World Congress of African Linguistics, Kyoto, Japan, August 2015.

Ezeh, P.C. 2008. Abuan nominal morphology. Unpublished BA long essay. Port Harcourt: University of Port Harcourt.

Ezeh, P.C. 2016. Abuan verb morphology. Unpublished MA thesis. Port Harcourt: University of Port Harcourt.

Faraclas, N.G. 1989. Cross River. In J. Bendor-Samuel The Niger-Congo Languages. Lanham: University Press of America, Inc. pp. 378-399.

Francstan, N.D. 1995. Nominal affixes in Ogbogolo. Unpublished BA long essay. Port Harcourt: University of Port Harcourt.

Gardner, A. and I. Gardner. 1966. Adinya опи Abuan. Jos: Institute of Linguistics. 
Gardner, A. and I. Gardner. 1971. Aselemi adibel adinya itugha onu Abuan. Ibadan: Institute of African Studies.

Gardner, A. and I. Gardner. 1973. Amaka: Adinya ogbaam araraar Abuan di Aselemi r'Amaka omiin ilo adio r'adio. Ibadan: Institute of African Studies.

Gardner, I. 1973. Asidum Abuan. Jos: Institute of Linguistics.

Gardner, I. 1980. Abuan-English dictionary. Port Harcourt and Jos: University of Port Harcourt and Nigeria Bible Translation Trust.

Gardner, I., A. Gardner and M. Abigo. 1974. Reading and writing Odual. Ibadan and Port Harcourt: Rivers Readers Project.

Gardner, I., S. Azugha, I.S. Moopho and M. Ofori. 1972. Awe areelhe kirokiro. Jos: Institute of Linguistics.

Gardner, I.D. 1975. Odual-English wordlist. Jos: Institute of Linguistics.

Givón, T. 1984. Syntax: A functional typological introduction I. Amsterdam/Philadelphia: John Benjamins Publishing Company.

Hargrove, M.B. 2009. Abuan odi. Port Harcourt: Pearl Publishers.

Isukul, C. 1986. On the morpheme -m- in Oggbịa. Anthropological Linguistics 28(2): 161-168.

Isukul, C.M. 2002. The modernized counting system in Ogbiạ. Port Harcourt: Emhai Publishing Co.

Isukul, C.M. 2007. Agholo nominal morphology. Unpublished doctoral dissertation. Port Harcourt: University of Port Harcourt.

Joshua, K. 2006. The basics of Abuan grammar. Port Harcourt: The Joe Publishers.

Kari, E.E. 2000. Ogbronuagum (the Bukuma language). Munchen: Lincom Europa.

Kari, E.E. 2003. Serial verb constructions in Degema, Nigeria. African Study Monographs 24(4): 271-289.

Kari, E.E. 2007a. Noun class vestiges in Odual. In O.-M. Ndimele (Ed.) Nigerian Languages, literatures, culture and reforms: A Festschrift for Ayo Bamgbose. Port Harcourt: M \& J Grand Orbit Communications Ltd. and Emhai Press. pp. 523-543.

Kari, E.E. 2007b. The pronominal system of Odual. Studies in African Linguistics 36(1): 91-113.

Kari, E.E. 2009. A grammatical description of the Odual language. Osaka: Research Institute for World Languages, Osaka University. 
Kari, E.E. 2011. Oḍual orthography. In O.-M. Ndimele (Ed.) Orthographies of Nigerian languages manual IX. Abuja: National Educational Research and Development Council. pp. 89-102.

Kari, E.E. and K.J. Joshua. 2011. Abuan orthography. In O.-M. Ndimele (Ed.) Orthographies of Nigerian languages manual IX. Abuja: National Educational Research and Development Council. pp. 1-12.

Lewis, M.P., G.F. Simons and C.D. Fennig (eds.) 2016. Ethnologue: Languages of the world $\left(19^{\text {th }}\right.$ ed.). Dallas, Texas: SIL International. Available online: http://www.ethnologue.com (Accessed 20 August 2016).

Lyons, J. 1968. Introduction to theoretical linguistics. Cambridge: Cambridge University Press.

Madumere, R.O. 2006. Verb morphology of Odual. Unpublished BA long essay. Port Harcout: University of Port Harcourt.

Ndimele, O.-M. 2003. A concise grammar and lexicon of Echie. Aba: National Institute for Nigerian Languages.

Ndimele, O.-M., E.E. Kari and J.G.I. Ayuwo. 2009. Language: Some historical implications. In E.J. Alagoa, T.N. Tamuno and J.P. Clark (Eds.) The Izon of the Niger Delta. Port Harcourt: Onyoma Research Publications. pp. 69-89.

Ngeripaka, J. 2000. The morphology of Obulom. Unpublished BA long essay. Port Harcourt: University of Port Harcourt.

Olibie, E.I. 1994. Towards the identification of the word classes in Ogbogolo. Unpublished BA long essay. Port Harcourt: University of Port Harcourt.

Omu, C.I. 1993. The Abuan counting system. Unpublished manuscript. Port Harcourt.

Otto, G. 2000. Abua in socio-economic perspective. Port Harcourt: Emhai Printing \& Publishing Co.

United Bible Society. 1974. Mạk. Lagos: The Bible Society of Nigeria.

United Bible Society. 1978. New Testament in Abuan. Lagos: The Bible Society of Nigeria.

Williamson, K. 1970. Reading and writing Ogbia. Ibadan: Rivers Readers Project, Institute of African Studies.

Williamson, K. 1972. Assimilation in Ogbia. University of Ibadan Research Notes 5: 1-5.

Williamson, K. 1989a. The Niger-Congo overview. In J. Bendor-Samuel (ed.) The NigerCongo Languages. Lanham: University Press of America. pp. 3-46. 
Williamson, K. 1989b. The Benue-Congo overview. In J. Bendor-Samuel (ed.) The NigerCongo Languages. Lanham: University Press of America. pp. 248-274.

Williamson, K. and R. Blench. 2000. Niger-Congo. In B. Heine and D. Nurse (eds.) African Languages: An introduction. Cambridge: Cambridge University Press. pp. 11-42.

Wolff, H. 1959. Niger Delta languages I: Classification. Anthropological Linguistics 1(8): 32-53.

Wolff, H. 1969. A comparative vocabulary of Abuan dialects. Evanston: Northwestern University Press.

Woodman, E. 1983. Affixation in Abuan. Unpublished BA long essay. Port Harcourt: University of Port Harcourt.

Woy, I.M. 1985. A history of Abua religion from 1880 to present day. Unpublished BA long essay. Port Harcourt: University of Port Harcourt. 